\title{
Long-Term Survival of an
} Elderly Patient with Carcinosarcoma of the Gallbladder after Cholecystectomy

\author{
Takashi Kohtani $^{a} \quad J^{\prime}$ Masuda ${ }^{b}$ Toshiko Hisaki $^{b}$ \\ Kouichi Shimase $^{c}$ Kunio Mizuguchid \\ aDepartment of Surgery, Yoshida Municipal Uwajima Hospital, Uwajima,

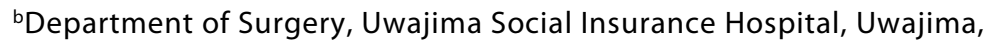 \\ 'Department of Surgery, Shimase Medical Clinic Hospital, Uwajima, and \\ dDepartment of Pathology, Teikyo University School of Medicine, Mizonokuchi \\ Hospital, Kawasaki, Japan
}

\section{Key Words}

Carcinosarcoma of the gallbladder - Long-term survival, elderly patient

\begin{abstract}
Carcinosarcomas, often referred to as malignant mixed tumors, are rare neoplasm. We reported herein a carcinosarcoma of the gallbladder in an elderly patient with long-term survival (4 years). The operation carried out was open cholecystectomy under the preoperative diagnosis of chronic cholecystitis and tumor of the gallbladder. Anticancer chemotherapy after cholecystectomy was performed by oral low-dose FT therapy. He was alive with no evidence of disease 48 months after surgery. Long-term survival for only cholecystectomy treatment as in this case may be possible if oral low-dose FT anticancer therapy is effective against carcinosarcoma of the gallbladder.
\end{abstract}

\section{Introduction}

Carcinosarcomas are rare tumors characterized by malignant epithelial and mesenchymal elements. These tumors have been reported in many different organs, including the uterus, lung, esophagus, and kidney [1]. We present a case with a longer-term survival than other surgically treated patients and considered to be a very rare case. 


\section{Case Report}

An 84-year-old man was admitted to Uwajima Social Insurance Hospital with right upper quadrant abdominal pain. Clinical examination disclosed tenderness in the right upper quadrant space. Blood examination showed leukocytosis (white blood cell count $12,100 / \mathrm{mm}^{3}$ ), serum glutamic oxaloacetic transaminase (GOT) level and $\gamma$-gultamyl transpeptidase level were elevated (GOT 78 IU/l and $\gamma$-GTP $191 \mathrm{IU} / \mathrm{l})$. Abdominal computed tomography revealed chronic cholecystitis and calcification in the gallbladder (fig. 1).

Open cholecystectomy was carried out under the preoperative diagnosis of chronic cholecystitis and tumor of the gallbladder. The gallbladder tumor was $7.0 \times 3.2 \times 3.2 \mathrm{~cm}$ in size, was located in the neck, and had calcification in parts (fig. 2), with slight invasion of the serosa. Regional lymph nodes were not swollen. Cholecystitis surrounded the tumor. TMN clinical classification of the tumor was T2 N0 M0. Microscopic examination showed that the neoplastic tissue consisted of two elements. The first element was highly cellular, composed of malignant epithelial cells such as adenocarcinoma. The other elements were malignant sarcomatous mesenchymal elements such as bone and cartilages that grew intermingled into each other (fig. 3a). We diagnosed carcinosarcoma of the gallbladder by immunohistochemical staining. Adenocarcinoma cells were stained by cytokeratin (fig. 3b), EMA, and not were stained by desmin and CD68. Sarcoma cells were stained by CD68 (fig. 3c) and were not stained by cytokeratin and EMA, which proved that it was not of epithelial origin, as mentioned above.

The postoperative course was uneventfully. Radical operation (such as hepatectomy with lymph node dissection) was not performed, therefore the family's consent was not obtained due to the patient's advanced age. Anticancer chemotherapy after cholecystectomy was performed by oral low-dose FT therapy. The patient was alive with no evidence of disease 48 months after surgery.

\section{Discussion}

The term carcinosarcoma was first used as a descriptive term by Virchow in 1864 [2]. Landsteiner, in 1907, described the first case of gallbladder carcinosarcoma, found in a museum specimen [3]. According to the previous literature, the incidence of carcinosarcoma of the gallbladder accounts for $1.7 \%$ of all the malignant tumors of the gallbladder [4]. To our knowledge, about forty cases of carcinosarcoma of the gallbladder have been reported to date $[4,5]$. Patients' age usually ranges from 45 to 91 years, and the incidence is higher in women than in men. Carcinosarcoma of the gallbladder is associated with cholelithiasis in $83 \%$ of cases [6]. The treatment of this disease is the same as that of other gallbladder cancer. The best treatment is surgical excision [7]. In our case, open cholecystectomy was performed. Then a radical operation (such as hepatectomy with lymph node dissection) was considered, but the family refused consent for this operation because of the advanced aged of the patient.

The prognosis of this disease is dismal, therefore the clinical setting and morbidity prognosis were similar to younger cases $[4-6,8,9]$. Patients often die within one year of the diagnosis. A world literature search revealed only nine cases of this disease in patients over 80 years old $[4-6,8,9]$, and there have been no reports of long-term survival (over 48 months) among surgically treated elderly patients for this disease. Our case is therefore considered to be the longest survival among elderly patients and to be very rare (table 1). This case had long-term survival and the reasons are as follows: (1) The tumor was so slow-growing because he was an elderly patient. (2) Long-term survival for surgically treated cases such as this one may be possible if the tumor shows only little invasion into the gallbladder serosa and can be completely excised by cholecystectomy. (3) We consider that oral low-dose FT anticancer therapy is effective against carcinosarcoma of the gallbladder. 
Table 1. All reported cases of gallbladder carcinosarcoma in elderly patients (over 80 years old) from the world literature

\begin{tabular}{|c|c|c|c|c|c|c|c|c|c|}
\hline \multirow[t]{3}{*}{ Authors } & \multirow{3}{*}{$\begin{array}{l}\text { Age/ } \\
\text { sex }\end{array}$} & \multirow{3}{*}{$\begin{array}{l}\text { Chief } \\
\text { complaint }\end{array}$} & \multirow{3}{*}{$\begin{array}{l}\text { Pre- } \\
\text { operative } \\
\text { diagnosis }\end{array}$} & \multirow{3}{*}{$\begin{array}{l}\text { Gall- } \\
\text { stone }\end{array}$} & \multirow{3}{*}{$\begin{array}{l}\text { Prognosis } \\
\text { (months) }\end{array}$} & \multirow[t]{3}{*}{ Treatment } & \multicolumn{3}{|l|}{ Pathology } \\
\hline & & & & & & & \multirow{2}{*}{$\begin{array}{l}\text { carci- } \\
\text { noma }\end{array}$} & \multicolumn{2}{|l|}{ sarcoma } \\
\hline & & & & & & & & bone & $\begin{array}{l}\text { carti- } \\
\text { lage }\end{array}$ \\
\hline $\begin{array}{l}\text { Yamagiwa, } \\
1971[10]\end{array}$ & $83 / \mathrm{F}$ & icterus & unknown & $\begin{array}{l}\text { un- } \\
\text { known }\end{array}$ & $\begin{array}{l}\text { un- } \\
\text { known }\end{array}$ & hepatectomy & Adeno & $\begin{array}{l}\text { leiomyo- } \\
\text { sarcoma }\end{array}$ & \\
\hline $\begin{array}{l}\text { Roth et al., } \\
1972 \text { [6] }\end{array}$ & $83 / \mathrm{F}$ & epigastralgia & unknown & $\bigcirc$ & 0 & unknown & Squamous & sarcoma & \\
\hline $\begin{array}{l}\text { Mansori } \\
\text { and Chou, } \\
1980[11]\end{array}$ & $81 / \mathrm{F}$ & $\begin{array}{l}\text { abdominal } \\
\text { pain }\end{array}$ & unknown & 0 & 0.5 & $\begin{array}{l}\text { hepatectomy, } \\
\text { cholecystectomy }\end{array}$ & Squamous & sarcoma $\bigcirc$ & 0 \\
\hline $\begin{array}{l}\text { von Kuster } \\
\text { and Cohen, } \\
1982[8]\end{array}$ & $91 / \mathrm{F}$ & $\begin{array}{l}\text { right upper } \\
\text { quadrant pain }\end{array}$ & unknown & 0 & 0 & biopsy & Adeno & $\begin{array}{l}\text { fibro- } \\
\text { sarcoma }\end{array}$ & \\
\hline $\begin{array}{l}\text { Born et al., } \\
1984 \text { [4] }\end{array}$ & $90 / \mathrm{F}$ & $\begin{array}{l}\text { nausea and } \\
\text { vomiting }\end{array}$ & unknown & $\bigcirc$ & 3 & cholecystectomy & & $\begin{array}{l}\text { fibro- } \\
\text { sarcoma }\end{array}$ & \\
\hline $\begin{array}{l}\text { Lumsdem, } \\
1988 \text { [12] }\end{array}$ & $81 / \mathrm{F}$ & $\begin{array}{l}\text { right upper } \\
\text { quadrant pain, } \\
\text { anorexia and } \\
\text { weight loss }\end{array}$ & $\begin{array}{l}\text { billiary } \\
\text { neoplasm }\end{array}$ & O & 1.5 & cholecystectomy & Squamous & sarcoma & \\
\hline $\begin{array}{l}\text { Fagot et al., } \\
1994 \text { [5] }\end{array}$ & $83 / \mathrm{F}$ & $\begin{array}{l}\text { fever and } \\
\text { vomiting }\end{array}$ & unknown & $\bigcirc$ & 12 & cholecystectomy & Squamous & sarcoma & \\
\hline $\begin{array}{l}\text { Takahashi } \\
\text { et al., } \\
2004 \text { [9] }\end{array}$ & $84 / \mathrm{F}$ & $\begin{array}{l}\text { right upper } \\
\text { quadrant pain, } \\
\text { back pain }\end{array}$ & $\begin{array}{l}\text { gall- } \\
\text { bladder } \\
\text { cancer }\end{array}$ & - & 2.3 & $\begin{array}{l}\text { cholecystectomy, } \\
\text { partial colectomy }\end{array}$ & $\begin{array}{l}\text { Undiffer- } \\
\text { entiated }\end{array}$ & sarcoma & \\
\hline $\begin{array}{l}\text { Our case, } \\
2008\end{array}$ & $84 / \mathrm{M}$ & $\begin{array}{l}\text { right upper } \\
\text { quadrant pain }\end{array}$ & $\begin{array}{l}\text { billiary } \\
\text { tumor, } \\
\text { chole- } \\
\text { cystits }\end{array}$ & - & 48 & cholecystectomy & Adeno & sarcoma $\bigcirc$ & 0 \\
\hline
\end{tabular}

Fig. 1. Computed tomography scan of the abdomen showed a gallbladder tumor in calcification and chronic cholecystitis.

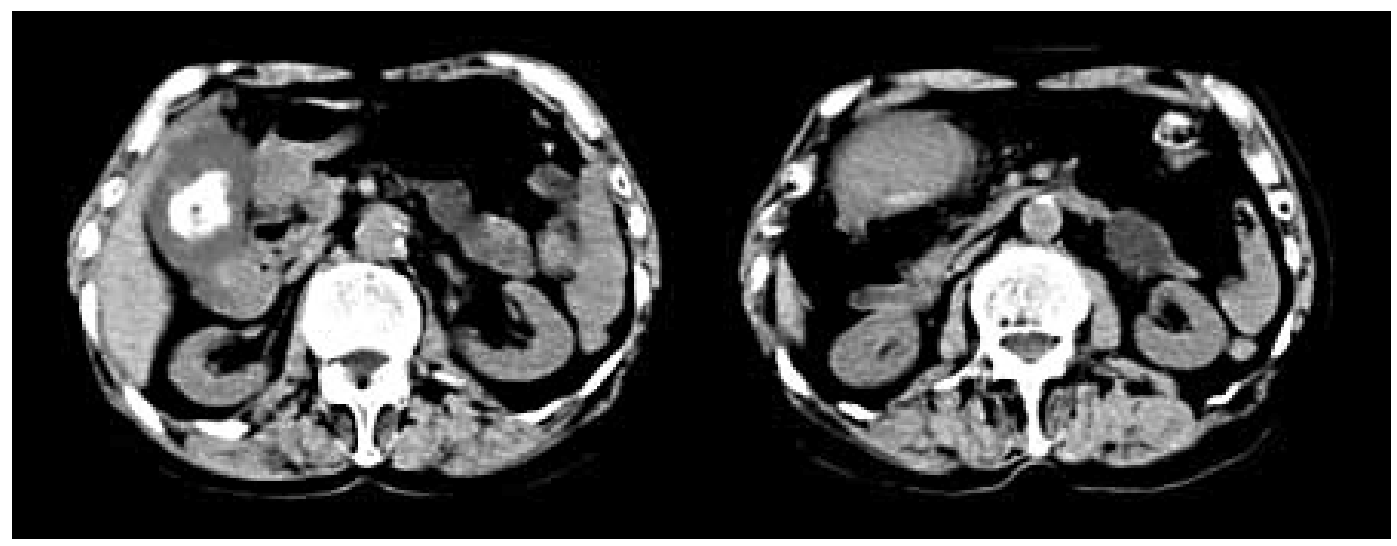




\begin{tabular}{|c|c|c|c|}
\hline $\begin{array}{r}\text { Case Reports in } \\
\text { Gastruenterdagy }\end{array}$ & $\begin{array}{l}\text { Case Rep Gastroenterol 2009;3:235-239 } \\
\text { Dol: 10.1159/000229592 }\end{array}$ & | Published online: August 28, 2009 & \begin{tabular}{|l} 
| ( 2009 S. Karger AG, Basel \\
ISSN 1662-0631 \\
www.karger.com/crg
\end{tabular} \\
\hline
\end{tabular}

Fig. 2. The resected specimen of the gallbladder. The tumor was $7.0 \times 3.2 \times 3.2 \mathrm{~cm}$ in size, was located in the neck and had calcification in parts.

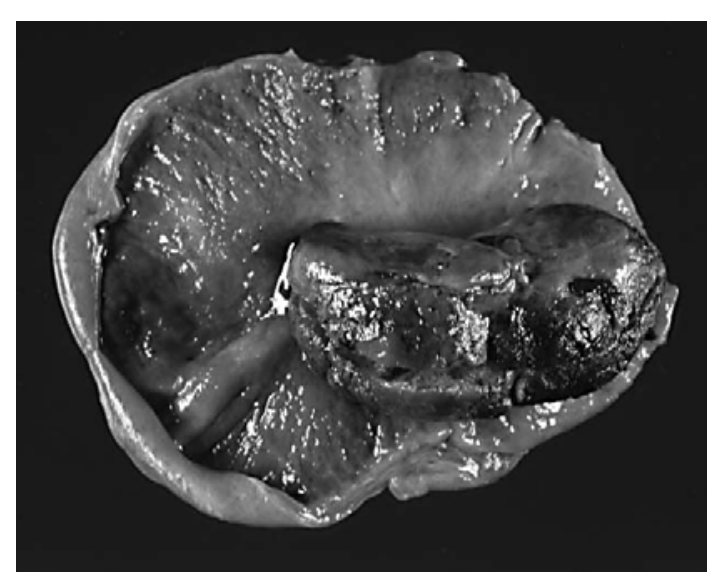

Fig. 3. Histological examination of the resected specimen. a Microscopic examination showed that the tumor cells were composed of adenocarcinoma and mesenchymal elements, such as bone and cartilage $(\mathrm{H} \& \mathrm{E} \times 100)$. b Immunohistochemical staining; adenocarcinoma cells were stained by cytokeratin ( $\times 200)$. c Immunohistochemical staining; sarcoma cells were stained by CD68, which proved that they was not of epithelial origin, as mentioned above $(\times 200)$.

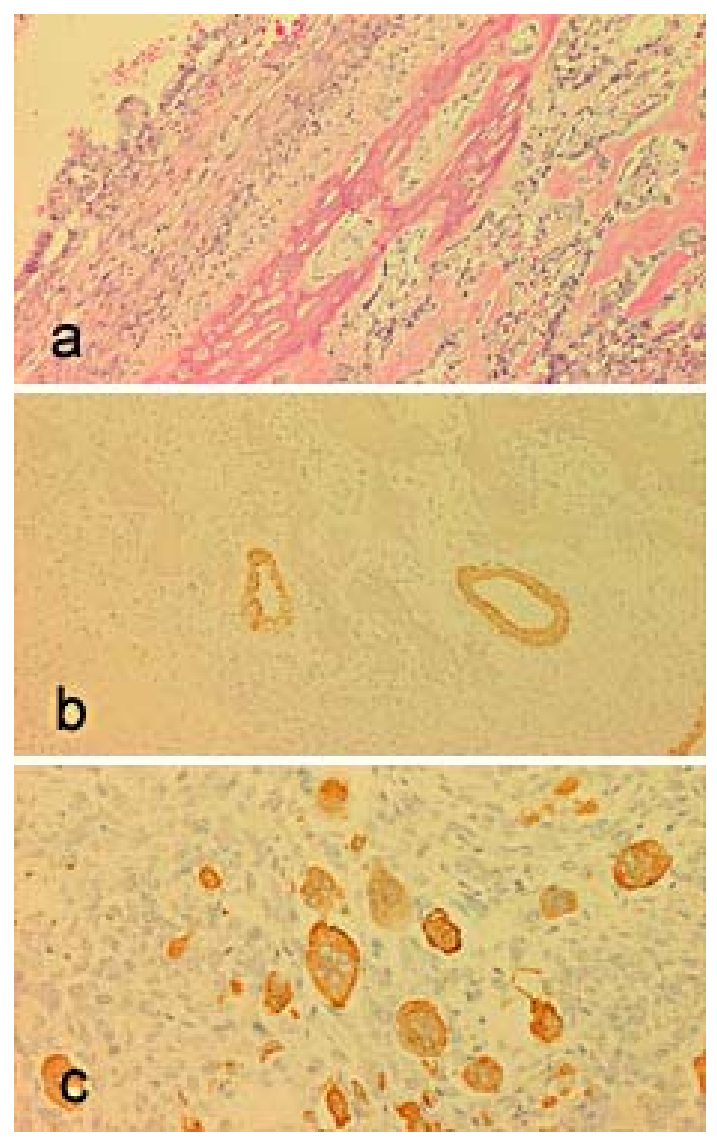




\section{References}

1 Silverberg SG, Kurman RJ: Tumors of the uterine corpus and gestational trophoblastic disease; in: Atlas of Tumor Pathology, 3rd series, fascicle 3. Washington, DC, Armed Forces Institute of Pathology,1992, pp 166-177.

2 Virchow R: Die krankhaften Geschwülste, vol 2. Berlin, August Hirschwald, 1864-1865, pp 181-182.

3 Landsteiner K: Plattenepithelkarzinom und Sarkom der Gallenblase in einem Falle von Cholelithiasis. Klin Med 1907;62:427-433.

-4 Born MW, Ramey WG, Ryan SF, Gordon PE: Carcinosarcoma and carcinoma of the gallbladder. Cancer 1984;53:2171-2177.

-5 Fagot H, Fabre JM, Ramos J, Laffay V, Guillon F, Domergue J, Baumel H: Carcinosarcoma of the gallbladder: A case report and review of the literature. J Clin Gastroenterol 1994;18:314-316.

-6 Roth J, Machnik G, Stiller D: Das Karzinosarkom der Gallenblase. Zentralbl Allg Pathol 1972;116:545-550.

7 Gall FP, Kocherling F, Scheele J, Schneider C, Hohenberger W: Radical operation for carcinoma of the gallbladder: present status in Germany. World J Surg 1991;15:328-336.

8 von Kuster LC, Cohen C: Malignant mixed tumor of the gallbladder: report of two cases and a review of the literature. Cancer 1982;50:1166-1170.

-9 Takahashi Y, Fukushima J, Fukusato T, Shiga J: Sarcomatoid carcinoma with components of small cell carcinoma and undifferentiated carcinoma of the gallbladder. Pathol Int 2004;54:866-871.

10 Yamagiwa H: A case of carcinosarcoma of the gallbladder (in Japanese). Mieigaku 1971;14:408-409.

11 Mansori KS, Chou SY: Malignant mixed tumor of gallbladder. Am Soc Clin Pathol 1980;73:709-711.

12 Lumsdem AB, Mitchell WE, Vohman MD: Carcinosarcoma of the gallbladder: a case report and review of the literature. Am Surg 1988;54:492-494. 